\title{
Analysis of Arabic Language Learning at Higher Education Institutions with Multi-Religion Students
}

\author{
Mahyudin Ritonga ${ }^{1, *}$, Asrina ${ }^{2}$, Rizka Widayanti ${ }^{3}$, Fitri Alrasi $^{1}$, Julhadi $^{4}$, Syaflin Halim $^{5}$ \\ ${ }^{1}$ Arabic Language Education Study Program, Faculty of Islamic Studies, Muhammadiyah University of West Sumatera, Indonesia \\ ${ }^{2}$ Department of Comparative School of Jurisprudence, Faculty of Sharia and Law, Imam Bonjol State Islamic University, Indonesia \\ ${ }^{3}$ Arabic Language Education Study Program, High School of Islamic Religion Darul Qur'an (STAIDA), Indonesia \\ ${ }^{4}$ Islamic Education Study Program, High School of Islamic Sciences Syekh Burhanuddin Pariaman, Indonesia \\ ${ }^{5}$ Islamic Law Study Program, Faculty of Islamic Studies, Muhammadiyah University of West Sumatera, Indonesia
}

Received May 15, 2020; Revised June 17, 2020; Accepted July 20, 2020

\section{Cite This Paper in the following Citation Styles}

(a): [1] Mahyudin Ritonga, Asrina, Rizka Widayanti, Fitri Alrasi, Julhadi, Syaflin Halim, "Analysis of Arabic Language Learning at Higher Education Institutions with Multi-Religion Students," Universal Journal of Educational Research, Vol. 8, No. 9, pp. 4333-4339, 2020. DOI: 10.13189/ujer.2020.080960.

(b): Mahyudin Ritonga, Asrina, Rizka Widayanti, Fitri Alrasi, Julhadi, Syaflin Halim (2020). Analysis of Arabic Language Learning at Higher Education Institutions with Multi-Religion Students. Universal Journal of Educational Research, 8(9), 4333-4339. DOI: 10.13189/ujer.2020.080960.

Copyright $\bigcirc 2020$ by authors, all rights reserved. Authors agree that this article remains permanently open access under the terms of the Creative Commons Attribution License 4.0 International License

\begin{abstract}
Arabic language learning, in Indonesia, is commonly addressed to those with Islamic Religion. However, there are several problems associated with learning this language in higher education institutions due to the mandated rule that students can learn it, irrespective of their religion. This research aims to reveal the institution's strengths, weaknesses, opportunities, and threats since the inclusion of the Arabic language in the higher educational institution's curriculum. A qualitative approach was conducted in this research equipped with the data sources of students, lecturers, and policy documents related to the curriculum establishment. The collected data were classified, presented, and interpreted before concluding. The result showed that the institution's strengths are the availability of lecturers with excellent Arabic language competences as well as a language and study center. In addition, by teaching Arabic, it creates more job opportunities for graduates. Meanwhile, the institution's weaknesses are lecturers' language incompetence in certain fields, which vary from different study programs or faculties. Furthermore, due to the location of the four different regencies, students from regencies are unable to utilize the provided facilities. In addition, the institution is faced with the possibility of losing prospective students that do not understand Arabic transcriptions.
\end{abstract}

Keywords Arabic Language, Learning, Curriculum, Institution

\section{Introduction}

The Arabic language is one of the international languages that is considered part of the educational curriculum in Indonesian higher institutions, including Universitas Muhammadiyah Sumatera Barat. According to the Rector's Decision Letter No. 252/KEP/II.3.AU/F/2016 on the Establishment of Institutional Compulsory Course at University Level, the Arabic language is not only taught in the Faculty of Islamic Religion, it is also a compulsory course. This means that all university students need to pass the Arabic language course without any exception, including those in Non-Islamic Religious Faculties such as Tourism, Health, Mathematics, and Natural Sciences. Furthermore, the Rector's Decision Letter No. 269/KEP/II.3.AU/F/2016 on Lecturers in Charge of University Level Courses has also been established and enforced. From the discussion results with the Team of Arabic Language lecturers, showed that they experienced difficulties in selecting the Arabic language learning materials and appropriate topics for each study program. In 
fact, they gave the same materials to various study programs in different faculties, using the al-'Arabiyyah bayna yadaik book.

The tendency to select the learning mentioned above source is inseparable from the backgrounds of lecturers that are greatly familiar with Arabic language texts containing Islamic studies, compared to those with social, economic, political, health, etc. Meanwhile, the frequent use of the Arabic language taught to university students in their academic and future life endeavors, seems to be quite low since the topics and themes taught are still far from those related to their knowledge and profession.

In response to these phenomena, language learning needs to be properly directed to emphasize students' competence to certain scientific aspects of cultural development and social needs. Therefore, Alhirtani, stated that the re-scientification idea needs to be followed up with various strategic methods, such as focusing the Arabic language learning on students' knowledge aspects[1]. Brosh also stated that various contexts need to be considered in selecting Arabic language learning materials [2]. These strategies aim to determine the uses of language, its field, and the profession.

This research therefore aims to analyze the strengths, weaknesses, and opportunities associated with the study of the Arabic language in higher education institutions. The analysis result of this research is a consideration for universities to determine policies related to the Arabic language implementation as a part of their curriculum.

Several aspects need to be considered in developing a language learning curriculum, namely institution's readiness [3], educators' ability [4], global development [5], and institution's vision [6]. In response to the development of learning materials, textbooks are one of the learning facilities with systematically organized tools selected based on purposes, orientation, and learners' development. Meanwhile, Al-Shabiel stated that some of the characteristics of learning materials are: 1) sources, 2) course references, 3) systematically and simply organized, and 4) the existence of guidelines. Lashley also asserts that the existence of learning materials and tight selection is greatly essential for both lecturers and teachers [7].

Wicita reported that basic competence standards, indicators, learning materials, and activities are some organizational strategies [8]. Learning materials are the contents of certain courses or fields of study given to learners based on the applicable curriculum. It covers the following: 1) learning instructions, 2) competences to achieve, 3) supporting information, 4) exercises, 5) working guidelines in the form of students' working sheets, and 6) evaluation[9]. According to the Center for Curriculums and Books (2008), the following aspects are used to pay attention in writing a book, namely: 1) content, 2) material presentation, 3) language and readability, and 4) graphic aspect. Besides, Richards stated that word choice or diction is used as an essential element used in developing a language. Richards' statement shows that there is a typical use of vocabularies in each community [6], which means that the language associated with Islamic studies differs from tourism, although it has the same meanings.

Meanwhile, studies on the development of Arabic language learning material have been previously conducted by many experts. These include Al-Qur'an learning materials, theme-based development material, competence, and contextual-based, etc. Besides teaching language, educators also strengthen students' knowledge [10]. However, the failure of Arabic language learning is also caused by the inexistence of related sources with specified purposes [11], [12]. The materials contained in the Arabic language learning book are $80 \%$ related to Islamic Dakwah. Approximately, $90 \%$ of the students in their last semesters in TAFL have competencies in the field of Arabic language competencies [13], while those related to medicine, engineering, tourism are constrained with the use of particular terms.

Arabic language learning with the topics of certain fields of knowledge, help those knowledgeable in certain fields to easily achieve related skills [14], [15]. Similarly, Tajuddin et al. stated that the materials used in language learning need to consider the students' knowledge competencies and backgrounds [16]. Hattie reported that educators, learners, and materials [17] are three essential elements that are interrelated to realize effective, efficient, and meaningful learning processes.

According to Al-Shbiel, all Arabic language materials are basically developed through research (qabil li al-bahtsi wa al-dirasiyah) [18], with fun, constructive, creative, and meaningful teaching approaches, strategies, and techniques. Language learning materials need to be in accordance with the main purposes [19], which includes communicating and exchanging ideas between people in the field of education, politics, economics, civilization, and social management. All humans' life aspects have specific languages and terms. Therefore, Arabic language learning sources are greatly required in each knowledge aspect.

The SWOT approach was used to determine the strengths, weaknesses, opportunities, and threats faced by the institutions in implementing the Arabic language as part of its curriculum. The SWOT analysis is determined from four points of view: strengths, weaknesses, opportunities, and threats.

In the SWOT analysis, the dominant and inhibitor factors greatly influence the development of established policies[20]. The intended dominant factors are strengths and opportunities, while the inhibiting factors are weaknesses and threats. SWOT analysis is a powerful instrument used to analyze the leaders' policies. It also enables educational institutions to reveal the influencing factors and strategies used to strengthen the applicable procedures. 


\section{Materials and Methods}

This is a qualitative research, with data collected and analyzed in the form of documents and numerical data. The data sources were firstly obtained from policy documents related to the curriculum at the University of Muhammadiyah, West Sumatra. Secondly, data were obtained from leaders of the rector, two vice-rectors, and 10 deans at the university on their views related to the implementation of Arabic at the university curriculum. And thirdly, data sources were from 9 Arabic lecturers stipulated by the Rector's Decree.

The data were collected through observation, interviews, documentation, and focus group discussions. Observations were used to determine the application of Arabic as an institutional curriculum in all faculties. At the same time, interviews are useful to obtain information from informants on their view of establishing it as an institutional curriculum. Documentation is used to obtain data available at the University and Faculty. The focus group discussion is intended to obtain data on how this policy is implemented and how the solution is applied to the problems. This research comprises of rector, vice-rector, dean, and Arabic language lecturers in the Muhammadiyah University of West Sumatra. Data were interactively analyzed, as shown in Figure 1.

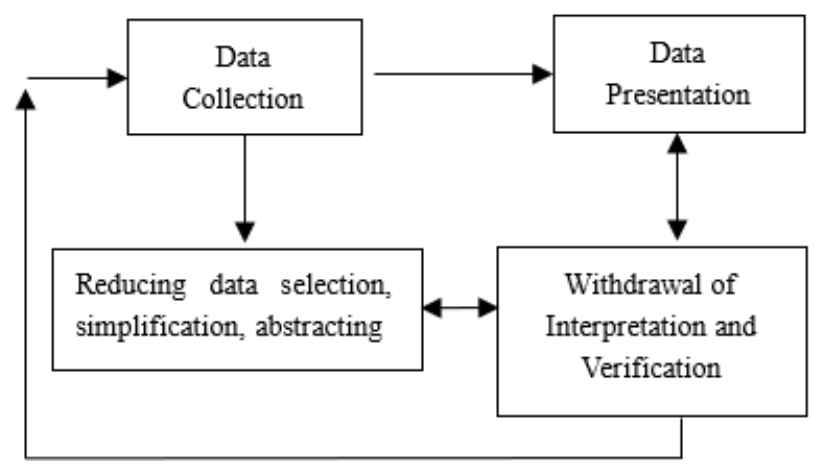

Figure 1. Data analysis

\section{Result and Discussion}

There are several strengths associated with the implementation of the Arabic language in higher education institutions' curricula, as shown in table 1.

Table 1 explained that the first institution's strength is human resources. Universitas Muhammadiyah Sumatera Barat has human resources that are competent in the Arabic language. As written in Rector's Decision Letter on educators teaching Arabic language, 8 (eight) lecturers are entrusted with teaching the language at the university level. All appointed human resources are competent in their particular field of study in accordance with their educational backgrounds and countries of origin where they have completed their studies.
Table 1. Institution's strengths in implementing the Arabic language as a part of the university curriculum

\begin{tabular}{|c|c|c|c|}
\hline \multirow{2}{*}{ No } & \multicolumn{3}{|c|}{ Research Findings } \\
\cline { 2 - 4 } & Strength & Aspect & Indicator \\
\hline \multirow{2}{*}{1} & $\begin{array}{c}\text { Human } \\
\text { Resources }\end{array}$ & Lecturers & $\begin{array}{c}\text { Have Arabic language } \\
\text { backgrounds }\end{array}$ \\
\cline { 4 - 4 } & $\begin{array}{c}\text { The existence of } \\
\text { Eaduated from Middle } \\
\text { East Universities }\end{array}$ \\
\hline 2 & $\begin{array}{c}\text { Arabic Language } \\
\text { Education Study } \\
\text { Program }\end{array}$ & Working & $\begin{array}{c}\text { Also participating in } \\
\text { Socializing the } \\
\text { importance of Arabic } \\
\text { language }\end{array}$ \\
\hline 3 & Ma'had al-Zubair & Working & $\begin{array}{c}\text { A place to strengthen } \\
\text { students' Arabic } \\
\text { Language competences }\end{array}$ \\
\hline 4 & $\begin{array}{c}\text { Language Center } \\
\text { and Laboratory }\end{array}$ & Working & $\begin{array}{c}\text { A place to learn Arabic } \\
\text { language either } \\
\text { independently or through } \\
\text { tutorials }\end{array}$ \\
\hline
\end{tabular}

The intended educational backgrounds are related to human resources with bachelor, master, or even doctoral degrees. The existence of these human resources is in accordance with the university leaders' intention for students to learn the Arabic language at the university. Besides being entrusted to teach the language, the human resources that completed their studies in Middle East countries are also experienced in the direct interaction with the native Arabic speakers.

The success associated with the implementation of a curriculum is not separated from the existence of human resources, especially educators [4], that precisely target the learning objectives [21], and teachers able to elaborate on the learning strategies[22]. Therefore, the existence of lecturers in realizing and succeeding in the implementation of the curriculum is significantly important. In this research, it is asserted that the entrusted lecturers that teach the Arabic language may re-explain the targeted learning objectives in the implementation of the Arabic language as the institution's curriculum.

The second is the existence of the Arabic language study program, which was introduced to the Islamic Religious Faculty in 2013. The Arabic language was introduced as part of the institution's curriculum due to its active existence and ability to support Al-Islam and Muhammadiyah principles courses to improve the students' motivation in various faculties.

Thirdly, Universitas Muhammadiyah Sumatera Barat also has a ma'had al-Zubair bin al-Awwam established based on the cooperation with AMCF. The existence of this institution provides a valuable contribution to strengthening Arabic language as the institution's curriculum. Therefore, this institution's contribution becomes noticeable when students are involved in the Arabic language learning activities. Therefore, concept and policy are greatly required by university leaders to be enforced and run by the ma'had (Islamic Boarding School) and faculty leaders.

Fourthly, the institution's language institution and 
laboratory existing in Universitas Muhammadiyah Sumatera Barat are one of the strengths used by the institution in implementing the Arabic language curriculum. The existence of a language laboratory is an important aspect used by students to learn the existing guidelines independently without the lecturers' assistance.

The second, third, and fourth aspects are the institutional units considered as the university's strengths in implementing Arabic language. These units play an important role and contribute to the field of language learning. Therefore, empowering these three units minimizes the university's various problems that tend to appear in the future.

\section{Institution's Weaknesses in Implementing the Arabic Language as a Curriculum}

Table 2 shows the data collected from observations, interviews, document studies, and focus group discussions:

Table 2. Institution's weaknesses in implementing the Arabic language as a part of the university curriculum

\begin{tabular}{|c|c|c|c|}
\hline \multirow{2}{*}{ No } & \multicolumn{3}{|c|}{ Research Findings } \\
\cline { 2 - 4 } 1 & Weakness & Aspect & Indicator \\
\hline 2 & $\begin{array}{c}\text { Faculty } \\
\text { Locations }\end{array}$ & Environment & $\begin{array}{c}\text { Some students have no } \\
\text { knowledge on Arabic } \\
\text { transcriptions }\end{array}$ \\
\hline 3 & $\begin{array}{c}\text { Learning } \\
\text { Sources }\end{array}$ & Facilities & $\begin{array}{c}\text { Not all students utilize } \\
\text { laboratory and ma had } \\
\text { because it is only available in } \\
\text { Padang city }\end{array}$ \\
\hline 4 & $\begin{array}{c}\text { Lecturers' } \\
\text { knowledge }\end{array}$ & Lecturers & $\begin{array}{c}\text { The utilization of learning } \\
\text { with the particular fields of } \\
\text { knowledge }\end{array}$ \\
\hline & $\begin{array}{c}\text { The Arabic lecturers are not } \\
\text { quite familiar with the terms } \\
\text { used in other fields of } \\
\text { knowledge. }\end{array}$ \\
\hline
\end{tabular}

The interpreted result from table 2 shows that students of universities Muhammadiyah Sumatera barat consist of those with various basic competence of Arabic transcription. However, some have no knowledge of this language, which is one of the institution's weaknesses associated with implementing the Arabic language. This statement is in accordance with the deans' discussion on the similarity of Arabic language learning system with the other courses' based on students' class of their registration year and not their backgrounds.

The Arabic language as the second language for Indonesian Students needs to encourage institutions to make policies based on their basic competences. It is in accordance with Alfares' statement that the diversity of language competence levels requires classification [23]. Ghani et al. also stated that learners' competence needs to be developed in accordance with the Arabic language learning modules [24].

The second is associated with separated faculty locations spread in four regencies/cities in West Sumatra regions. This is one of the institution's weaknesses in implementing the Arabic language as a part of the university curriculum. This statement is based on the availability of several factors supporting the success of curriculum implementation, such as a laboratory, ma'had al-zubair, and Arabic language education study program, which is only available in Padang.

Thirdly, it acts as a learning source, based on the result of interviews, observation, and documentation study. This showed that the source used in learning Arabic language in each study program was only a- 'Arabiyyah bayna yadayk. This reality led to the students' statements, which stated that the Arabic language is not important since it was not following their fields of knowledge. Learning the language is associated with the related topics used to motivate students [25]. Each learner becomes more motivated when they have an idea of the subject of study beforehand. In response to these weaknesses, the lecturer team through workshop activities need to organize the Arabic language learning in accordance with the study program [26] by involving experts.

Fourthly, the Limited Human Resources at Universities Muhammadiyah are considered good in terms of quantity and quality. However, when dealing with the Arabic language, knowledge competences in the other various fields [27] are still considered highly inadequate. The Arabic language lecturers are able to talk generally on the context of religious fields. Meanwhile, in the certain knowledge of other fields, such as engineering, agriculture, health, forestry, the lecturers are less familiar with the terms used.

Each field of knowledge has its own languages and interpretations. Therefore, the Arabic language learning needs to be in accordance with the learners' contents of knowledge [28], [29]. These lecturers' conditions result in the utilization of learning sources at universitas Muhammadiyah, which is not in accordance with the students' knowledge. Therefore, the leaders need to facilitate the lecturers to have Arabic language competences in various fields of knowledge, to accommodate all study programs available in the university.

\section{Institution's Opportunities in Implementing the Arabic Language as a Part of University Curriculum}

In accordance with the research data, it can be explained that institutions have the opportunities to implement the Arabic language as the institution's curriculum, as shown in table 3. 
Table 3. Institution's opportunities in implementing Arabic language as university curriculum

\begin{tabular}{|c|c|c|c|}
\hline \multirow{2}{*}{ No } & \multicolumn{3}{|c|}{ Research Findings } \\
\cline { 2 - 4 } 1 & Opportunity & Aspect & Indicator \\
\hline \multirow{2}{*}{2} & $\begin{array}{c}\text { Strengthening } \\
\text { AIK }\end{array}$ & Curriculum & $\begin{array}{c}\text { AIK is the spirit of } \\
\text { Muhammadiyah Higher } \\
\text { Education Institution }\end{array}$ \\
\hline 3 & $\begin{array}{c}\text { Expanding job } \\
\text { opportunities } \\
\text { Strengthening } \\
\text { thstitution's } \\
\text { identity }\end{array}$ & Output & $\begin{array}{c}\text { Foreign language } \\
\text { competences facilitate } \\
\text { the university graduates } \\
\text { to obtain various jobs }\end{array}$ \\
\hline
\end{tabular}

The table shows that in strengthening AIK learning, the Arabic language is established as a part of the institution's curriculum and a great opportunity for the institution to succeed the Al-Islam Muhammadyah [30]. AIK, as the spirit of Muhammadiyah Higher Education Institutions, needs to be properly supported by Islamic Teachings that are sourced from Al-Quran and Hadith [31].

In this context, the institution also has the opportunities to strengthen the cooperation between the Arabic language and AIK lecturers in integrating learning contents. As a religion that uses learning sources with Arabic language references, individuals willing to correctly and widely understand Islam need to use AIK [32],[33]. When the cooperation between the Arabic language and AIK lecturers is properly realized, the integrated knowledge at Universities Muhammadiyah Sumatera Barat is achieved.

The second is related to the graduates' job opportunities. In this industrial revolution era, foreign language competences are one of the main strategies used to secure a job [34],[35]. When the implementation of the Arab language as a part of the institution's curriculum is properly carried out, the expected quality, are also expected to have good language competences that they have opportunities to work in Middle East countries openly.

The third is related to strengthening the institution's identity in accordance with its vision "well known in Sumatra in integrating knowledge and Islam." In this case, the Arabic language is implemented as part of the institution's curriculum and automatically strengthened. This is because Arabic language and Islamic sciences are inseparable[36] and almost impossible for someone to integrate certain knowledge [37] of Islam without its use.

\section{Institution's treats in Implementing the Arabic language at University Curriculum}

The institution's threats in implementing the Arabic language as university curriculum are presented in the following table 4:

Table 4 showed that the institution's threats in implementing Arabic language as a part of the curriculum include: its establishment as part of the institution's curriculum and a threat in recruiting university students, which is limited to Muslim and non-Muslim students, such as Christians. It is possible for Christians in various countries to learn Arabic[38],[39] Yet, it is different that many Indonesians still think it is part of the Islamic religion. In fact, learning language according to the four main skills has nothing to do with religion or faith.

Table 4. Institution's threat in implementing Arabic language as university curriculum

\begin{tabular}{|c|c|c|c|}
\hline \multirow{2}{*}{ No } & \multicolumn{3}{|c|}{ Research Findings } \\
\cline { 2 - 4 } & Threat & Aspect & Indicator \\
\hline 1 & Students & Students & $\begin{array}{c}\text { The existence of non-Muslim } \\
\text { students }\end{array}$ \\
\hline 2 & Lecturers & Lecturers & $\begin{array}{c}\text { Number of lectures are not in } \\
\text { accordance with the study } \\
\text { program }\end{array}$ \\
\hline 3 & $\begin{array}{c}\text { Infrastruc } \\
\text { ture and } \\
\text { Facilities }\end{array}$ & $\begin{array}{c}\text { Infrastructu } \\
\text { re and } \\
\text { Facilities }\end{array}$ & $\begin{array}{c}\text { Not in accordance with the } \\
\text { qualified learning } \\
\text { requirements }\end{array}$ \\
\hline
\end{tabular}

Therefore, university leaders are expected to make policies related to the position of Arabic language course for non-muslim students irrespective of its ability to damage the system.

Secondly, the existence of the Arabic language in each study program has become the institution's threat to the lecturers' distribution of all study programs. Assuming the number of human resources is not in accordance with the study programs, and then it is certain that there is an unequal number of course credits. Therefore, each faculty leader needs to make a clear communication with the course-coordinating lecturers to divide $50 \%$ of Arabic language schedules to the odd semester and the other 50\% to the even semester.

The third is the infrastructure and facilities. The existence of the Arabic language as an institutional course also requires an effort to improve the quality and quantity of infrastructure. Learning a foreign language may not become effective and efficient when not supported by adequate infrastructure and facilitates. However, when the leaders fail to make efforts to fulfill those infrastructure and facilities related to Arabic language learning, as an institutional course, it becomes a completion of the course credit system (SKS), which the students may not enjoy the results.

\section{Conclusions}

The result of this research has successfully revealed the institution's strengths, weaknesses, opportunities, and threats in establishing and implementing the Arabic language as a part of their curriculum. Therefore, appropriate forms of learning sources are utilized by each study program in learning the Arabic language. 


\section{REFERENCES}

[1] N. A. K. Alhirtani, 'The Use of Modern Teaching Methods in Teaching Arabic Language at Higher Education Phase from the Point View of Arabic Language Professors-A Case of a Premier University', Int. Educ. Stud., vol. 13, no. 1, pp. 32-41, 2020.

[2] H. Y. Brosh, 'Arabic Language-Learning Strategy Preferences Among Undergraduate Students', Stud. Second Lang. Learn. Teach., vol. 9, no. 2, pp. 351-377, 2019.

[3] S. Rajurkar, K. D. Chavan, S. G. Kachewar, and P. A. Giri, 'A Review of Significant Aspects Contributing to Curriculum Development', Int. J. Res. Med. Sci., vol. 7, no. 1, pp. 1-6, 2018.

[4] M. A. Alsubaie, 'Curriculum Development: Teacher Involvement in Curriculum Development', J. Educ. Pract., vol. 7, no. 9, pp. 106-107, 2016.

[5] M. Priestley and S. Phillppou, 'Debate and Critique in Curriculum Studies: New Directions?', Curric. J., vol. 30, no. 4, pp. 347-351, 2019.

[6] J. C. Richards, Curriculum Development in Language Teaching, no. 1. Cambridge: Cambridge University Press, 2001.

[7] L. Lashley, 'A Reflective Analysis of the Selection and Production of Instructional Material for Curriculum Delivery at the Primary Level in Postcolonial Guyana', SAGE Open, vol. 9, no. 2, pp. 1-15, 2019.

[8] G. G. Wicita, 'A Set of English Instructional Materials Using Task-Based Learning for News Production Management Study Program in STMM "MMMTC" Yogyakarta', Lang. Lang. Teach. J., vol. 18, no. 1, pp. 63-73, 2015.

[9] H. Timperley, A. Wilson, H. Barrar, and I. Fung, Teacher Professional Development and ICT: Strategies and Models, vol. 109, no. 14. New Zealand: Teachers College Record, 2007.

[10] T. Souriyavongsa, S. Rany, M. Jafre Zainol Abidin, and L. Lai Mei, 'Factors Causes Students Low English Language Learning: A Case Study in the National University of Laos', Int. J. English Lang. Educ., vol. 1, no. 1, pp. 179-192, 2013.

[11] M. Yusuf and I. S. Wekke, 'Teaching and Learning Arabic and Quran Through Ecletic Method in Islamic School', Int. J. Pure Appl. Math., vol. 119, no. 18, pp. 915-927, 2018.

[12] M. Mall and M. Nieman, 'Problems Experienced With the Teaching of Arabic to Learners in Muslim Private Schools in South Africa and Botswana', Per Linguam, vol. 18, no. 2, pp. 42-54, 2002.

[13] F. Y. Al-Busaidi, 'Arabic in Foreign Language Programmes: Difficulties and Challenges', J. Educ. Psychol. Stud. [JEPS], vol. 9, no. 4, pp. 701-717, 2015.

[14] H. Taha-Thomure, 'The Status of Arabic Language Teaching Today', Educ. Bus. Soc. Contemp. Middle East. Issues, vol. 1, no. 3, pp. 186-192, 2008.

[15] N. M. Alhajya, S. S. Alzaghamim, and Y. M. Arouri, 'The Impact of Virtual Trips on the Development of Arabic Language Oral Skills Among Third Grade Students in Jordan', J. Technol. Sci. Educ., vol. 8, no. 1, pp. 72-85,
2018.

[16] S. Tajuddin, M. Kamal, and Z. Zuryati, 'Arabic Material Development Design for Senior High School', Arab. J. Pendidik. Bhs. Arab dan Kebahasaaraban, vol. 6, no. 1, pp. 93-107, 2019.

[17] J. A. C. Hattie and G. M. Donoghue, 'Learning Strategies: a Synthesis and Conceptual Model', npj Sci. Learn., vol. 1, no. 1, pp. 1-13, 2016

[18] A. O. Al-Shbiel, 'Arabization and Its Effect on the Arabic Language', J. Lang. Teach. Res., vol. 8, no. 2, pp. 469-475, 2017.

[19] A. H. El-Omari and H. M. Bataineh, 'Problems of Learning Arabic by Non-Arabic Speaking Children: Diagnosis and Treatment', J. Lang. Teach. Res., vol. 9, no. 5, pp. 10951101, 2018.

[20] E. Gurel and M. TAT, 'Swot Analysis: A Theoretical Review', Uluslararası Sos. Araştırmalar Derg. J. Int. Soc. Res., vol. 10, no. 51, pp. 994-1006, 2017.

[21] T. Roxå and E. Marquis, 'Teachers Interacting With Students: an Important (and Potentially Overlooked) Domain for Academic Development During Times of Impact', Int. J. Acad. Dev., vol. 24, no. 4, pp. 342-353, 2019.

[22] F. Fajriah, 'Improving Teaching Strategies Through Students' Reflections', Sukma J. Pendidik., vol. 1, no. 2, pp. 301-327, 2017.

[23] N. Alfares, 'Benefits and Difficulties of Learning in Group Work in EFL Classes in Saudi Arabia', English Lang. Teach., vol. 10, no. 7, p. 247, 2017.

[24] K. A. Ghani, N. M. R. Nik Yusof, H. Baharuddin, H. Yamat, Z. Ahmad, and I. Abdullah, 'Development of a Learning Module on Arabic Language Skills Outside of the Classroom', Procedia -Social Behav. Sci., vol. 18, pp. 154162,2011

[25] H. Brosh, 'Motivation of American College Students to Study Arabic', Int. J. Humanit. Soc. Sci., vol. 3, no. 19, pp. 27-38, 2013

[26] M. Alhamami, 'Teaching Science Subjects in Arabic: Arab University Scientists' Perspectives', Lang. Learn. High. Educ., vol. 5, no. 1, pp. 105-123, 2015.

[27] Warnis, H. W. Triana, Remiswal, M. Kustati, and Nelmawarni, "Arabic Langauge As The Icon of Islamic Higher Education: A Study of the Implementation of Arabic Intensive Program', Tarbiya J. Educ. Muslim Soc., vol. 6, no. 1, pp. 103-116, 2019.

[28] A. Fatoni, 'Arabic Learning for Academic Purposes', Izdihar J. Arab. Lang. Teaching, Linguist. Lit., vol. 2, no. 2, p. 149,2019

[29] M. Yusuf and I. S. Wekke, 'Active Learning on Teaching Arabic for Special Purpose in Indonesian Pesantren', Procedia - Soc. Behav. Sci., vol. 191, pp. 137-141, 2015.

[30] I. Zukdi, 'Learning Al-Islam and Kemuhammadiyahan in College Muhammadiyah', in ATLANTIS PRESS: Advances in Social Science, Education and Humanities Research (ASSEHR), 2019, vol. 293, no. Nfeic 2018, pp. 38-41.

[31] N. Selim, 'Muslim Societies' Ambivalence to Arabic: 
Reasons, Manifestations and Consequences', Int. J. Islam. Thought, vol. 11, no. 1, pp. 30-42, 2017.

[32] H. Dia, C. Hugon, and R. D'Aiglepierre, 'États Réformateurs et Education Arabo-Islamique en Afrique Vers un Compromis Historique? Introduction Thématique', Afr. Contemp., vol. 257, no. 1, pp. 11-23, 2016.

[33] H. Mat and W. M. U. W. Abas, 'The Relevance of Arabic Language in Islamic Studies Program: a Case Study of Open University Malaysia (OUM)', J. Educ. Soc. Sci., vol. 5, no. 2, pp. 205-209, 2016.

[34] B. Eberhard et al., 'Smart Work: The Transformation of the Labour Market Due to the Fourth Industrial Revolution', Int. J. Bus. Econ. Sci. Appl. Res., vol. 10, no. 3, pp. 47-66, 2017.

[35] M. H. Lee et al., 'How to Respond to the Fourth Industrial Revolution, or the Second Information Technology Revolution? Dynamic New Combinations Between
Technology, Market, and Society Through Open Innovation', J. Open Innov. Technol. Mark. Complex., vol. 4, no. 3, pp. 124, 2018

[36] S. Akkach, 'Ilm: Science, Religion and Art in Islam, no. 1. Adelaide: University of Adelaide Press, 2019.

[37] D. Ekawati, 'Urgency of Arabic in Islamic Education', Int. J. Arab. Lang. Teach., vol. 1, no. 2, pp. 209-222, 2019.

[38] H. Murre-Van den Berg, 'The Language of the Nation: The Rise of Arabic Among Jews and Christians (1900-1950)', Br. J. Middle East. Stud., vol. 43, no. 2, pp. 176-190, 2016.

[39] K. O. Ajape, A. Mamat, and Y. A. Azeez, 'Students' Motivation and Attitude Towards the learning of Arabic Language: A Case Study of Arabic Students in Nigerian Universities', in International Journal of Economics and Financial Issues, 2015, vol. 5, no. February, pp. 122-127. 